\title{
Common Language
}

\author{
Houria Abdelouahed \\ Université Paris-Diderot, Paris, France
}

\begin{abstract}
Injury of narcissism, the precarious situation, religion, fanaticism, ideal, humiliation, shame... All are themes that I find in my work with Syrian refugees. As a translator of poetry (especially that of Adonis), my remarks will focus more specifically on language. My patients who come from Syria speak Arabic say that they find their country in my office. How can we work on the entanglement of the individual and the collective when using a common language? How can psychic movement be revived in patients suffering from the traumas of war? How could the analyst, who speaks the patient's language in a foreign country, re-occupies the position of a foreigner who listens to the transferential movements?
\end{abstract}

Keywords: narcissism, precarious situation, religion, language, refugees

Have you ever been trembling with fear whilst waiting for your patients? What mental state will they be in? And when they arrive, are you already looking out for the slightest sign on their face? Watching houses being blown up, fights intensifying and towns turning to ruins, did you think of your patients during the holiday?

With more bombs falling on Aleppo, Homs becoming a ghost town and Raqqa, a Daesh stronghold, being targeted in turn by the armies of Bashar Al-Assad and the coalition, anxiety seizes me more and more as I wait for my Syrian patients: people from Aleppo, Homs, Dar'a or Damascus, Muslims of confession, Christians or Druze.

Most of them have held high positions in their country of origin: university professors, engineers, artists or students... They have experienced the path to exile. The cases differ. Some fled Syria right at the start of the war, others arrived after experiencing hunger, and others saw corpses...

The first thing that they talk about is the guilt they feel for "abandoning" members of their family in a country where the dying does not stop. The lack of food and water; corpses filling the roads and being thrown by volunteers into mass graves; and the deafening thud of bombs spark an acute anxiety. One saw their friend, a musicology student, collapse before their eyes as he was coming back from the Conservatoire; another's husband left to search for food and never returned; someone else's father braved the danger to check that his daughter's house had not been hit by the bombs, but was hit by a shell as he returned.

One describes how whole families are pulverised in landslides or crushed under collapsing buildings. Another explains how their daughter became deaf because of the bombs. They talk of children who develop kwashiorkor, or syndromes similar to autism, in which they put their fingers in their ears and turn round and round. Mothers cry when children don't finish their food, others cry because they don't have anything to put on the plate. Children who have arrived in France cry in the school canteen as soon as they see green salad, incapable of forgetting the grass being destroyed during the siege of Damascus...

Houria Abdelouahed, Ph.D., Lecturer, Université Paris-Diderot. 
The accounts are of a daily life that is weighed down by famine and threat. They are shocking stories, shattering and appalling, which make you nauseous as your body wants to eject that which is so bad it remains indigestible (Freud, 1925b). We have often repeated the phrase of Freud: "we descend from a line of criminals" (Freud, 1940); the cruelty confronts the psyche with the unimaginable, with that which it is unable to retain. The accounts, punctuated by sobs and moans, render the unbearable visible. The words of patients merge with those from the television and internet, and the horrors we see freeze our bodies and minds. We see a country ravaged by a war which exterminates, crushes, ravages, burns, consumes, engulfs and devours the images of a brutal instinct.

These are the images that give a particularity to this war. The gaze is sickened at the sight of a little girl or a young teenager being raped and savagely murdered by Daesh soldiers for being Christian—and as if that is not enough, the murderers stick a cross in the mouth of the young teenager. Or we see a video of a woman killed in the public square by Nosra soldiers (members of an Islamist faction), and accused of having unlawful sexual relations. The video sequence takes several minutes: the woman begs her executioners to spare her life, the man's revolver is pointed at the woman's head, she continues to plead, men surround her, an Islamist informs her of her sins... the woman struggles against death, which comes after never-ending torture. We see bodies of people killed by coalition strikes that missed their target, or corpses lined-up after chemical attacks by the government forces. All those innocent civilians die senselessly. The archaeologist whose throat was slit, and the women abducted by the Islamic State are loaded into trucks to be sold. Whole villages are emptied of their women, boys without mothers, husbands without wives, brothers without sisters. We can find the prices of these women on the internet: the youngest is the most expensive. The image that everyone saw of the little Aylan, washed up on the beach in Turkey, appears in our session through the howls of my patient. Before thinking in terms of identification (it is a mother who speaks), I feel myself shaken by the cruelty of the war and the damage that it causes, by the shock at seeing the Hungarian photographer carelessly kick the refugees, by the denial that they even belong to the human species.

What does the analyst feel when their gaze and ears are so weighed down by the unbearable things that they have seen and heard? The distant (Syria) appears in the here and now of the session, raising several themes: religion, exile, language, disappearance, dictatorship. "It could happen to us", said a Syrian analyst whilst she was working with Iraqi refugees (Abdelouahed, 2015). How could this work allow us to question the parameters of analysis: the regularity of sessions, payment, neutrality, appropriate distance, and asymmetry?

Should we remain orthodox in these circumstances - when we receive patients who have experienced such terrifying hunger, thirst, and homelessness that thought becomes confused? How should each session be produced with what strength and what weakness? In this context, how does clinical and psychoanalytical work invent and reinvent itself? How can we remain neutral, but also compassionate? How can the essential asymmetry of the analytical situation be re-established? And how can we find an appropriate distance when we ourselves have known and have worked in their country, and when all their stories are told in a common language?

The common language is Arabic. Common language means linguistic signifiers, but also the beauty of landscape, the colour of the sky, sensoriality, a shared history, the threat of fundamentalism and an uncertain future.

In a sense, my patients find their country in my office. What on the shelves are books in Arabic: novels and texts on mysticism and linguistics. The books are in a language (the mother tongue) whose musicality we both share. They are in the intimacy of this sharing. 
Things become clearer in hindsight:

Maha arrives for her first session. Her whole being groans. The effect is so huge that her speech is disrupted. Little by little, questions emerge: why didn't she stay there? Why did she flee? Was it not cowardly to have fled whilst her parents live the daily nightmare? Did she not betray all those she loved, as well as her principals? She wishes to die.

Transferentially, I am on the side of life. From the start of this one-to-one work, which became analysis, I attempted to instill a desire to live with silence, a respectful attitude and the few words that I uttered. "You are a mother and you were surely right to come and live in France with your husband and children". These words reminded her that she was more the mother of her children than the daughter of her parents. My words dig into the entanglement between collective trauma and its oedipal problematic.

Nawal arrived with a question that, in retrospect, can be translated thus: how can we discuss oedipal hostility towards the mother whilst she is risking her life each time she goes out to buy medicine or food? What is going through the patient's mind when, faltering as she talks of the precariousness of her living conditions, she states that her father doesn't wash himself anymore? He is like a homeless person, she adds - thereby mixing hostility towards him with love for him.

The image of a homeless person is also evoked by Maha on her way to the session she had passed a homeless person and was shocked by the folly of man. It was a way of expressing an attraction to the depths of melancholy, as well as the struggle not to sink into them. Analysis brings out the memory of her father being imprisoned by the old regime (of Hafez El-Assad) and her guilt at not being able to save him (she was 6 years old). She says that she should have warned her father when she saw the police approaching, but they were too quick. She speaks of a dream in which her feet are paralysed and she is unable to run.

As for Nizar-just as he is starting to deconstruct the effects on him of a culture which glorifies the parent figures, and to attack the paternal imago, the war starts to rage and puts an end to this work. How could he de-idealise a father that is threatened by Daesh—like the rest of the Druze family?

Jamila says: "I don't want to go to these demonstrations about Syria anymore. It's very perverted and these accounts of horror”. During our sessions, she talks to me only of the horror.

"Who will bury my parents if they die under the bombs?" is a recurrent question.

Ghunter Perdigao raises several questions, with much subtlety and precision, surrounding the injury of narcissism, precariousness, shame, and the idea that European identity is being threatened by the arrival of Muslim refugees. I'd like to respond to this last issue. My college talked about refugees as if they are all Muslims who bring with them other cultural codes and references. But not all the refugees are Muslim. And amongst the Muslims there are academics, engineers, doctors...intellectuals who are used to a "western" way of life.

As I was reading my colleague's text on identity, I thought of ancient Phoenicia in its flight to Europa and Io (Geffroy, 2015). Io gave her name to the straits of the Bosphorus (Bosphorus, according to the Greek etymology, means "passage of the cow") and to the Ionian Sea. Europa gave her name to the whole continent. Io, born on European soil, swam across the seas, passed to Asia finding refuge in the Caucasus, and finished her journey in Egypt where she resumed her human form. Europa went the opposite way. She was a Phoenician abducted by Zeus disguised as a white bull, and she rode across the seas towards the West. Her divine lover took her to Crete. While Europa languished, her brother Cadmus, searching for her, also came to the country and stopped short when he saw a superb white cow in a meadow. Cadmus saw it as a sign that it is here in Boeotia that he must finish his journey and find the city of Thebes. 
First, Cadmus had to draw water from a source. But this source, that of Ares, the God of war, was guarded by a dragon that Cadmus killed. Furious, Ares threatened to make Cadmus his slave. Cadmus, who owed his survival to the intervention of Athena, was told to remove the teeth of the dragon and then sow them in the plain. This is what he did. No sooner had he sowed the teeth in the ground than a warrior, armed in helmet and breastplate, emerged from each of them. These warriors were indigenous; "arising from the earth". They were the Sparti, the sown men. They were uncontrollably violent. Fearing that they would turn against him, Cadmus found a trick: he threw a stone in the midst of the Sparti and each of the warriors accused the other of having provoked him. They killed each other. The massacre was between the indigenous people, not the foreigners. Only five survivors remained who, thanks to the intervention of Harmony, goddess of reconciliation, participated in the founding of Thebes under the leadership not of an indigenous person, but of a foreigner, Cadmus.

So, the violence that was initially directed against the foreigner turned soon against the indigenous people. It only subsided thanks to reconciliation with the foreign element. The myth explains that all identity is steeped in otherness, and that otherness is always in motion.

With the massive influx of refugees, the question of the familiar and the foreign has taken a populist turn. The foreigner $=$ the exterior (outside) $=$ bad, said Freud in Instincts and Their Vicissitudes (Triebes und Triebeschicksale, 1915), a metapsychology text written while the First World War was raging. In times of crisis the foreigner becomes a surface of projections for those who advocate "the narcissism of small differences", according to Freud's expression (Freud, 1985c). We can also put forward the following hypothesis: the arrival of the foreigner awakens a feeling of the uncanny (Unheimlich) (Freud, 1985a). It makes us question the unknown foreignness deep within us. The Arabic term al-gharib (the foreigner), in its polysemy, embraces the intimate. To hear the word al-gharib is to see how the distant meets the near, and how the outside loses itself in a constitutive inside. It is a way of saying that all identity is made of otherness.

In reality, the refugees talk precisely of the injury at being considered to be bad people, to have lost their land and to be badly welcomed. In order to obtain refugee status, they have to recount a linear story even though time may seem frozen, a narrative that is well sewn even though the unrepresentable defeats and defies any attempt to be placed in a narrative. The trauma is such that it evades being put into words. Faced with an inability to articulate anything clearly in front of the administrative services (such as the OFPRA), a vague story runs the risk of being considered a false testimony (Fédida, 2007).

The trauma thus becomes "endless trauma", as Claude Janin put it (Janin, 1996). Humiliated by the prefecture officials, an academic patient says to me: "how can I make this woman understand that she is speaking to a human being?” On a transferential plan, she asks me to be humane, to be sensitive to her pain, to accept her suffering, to share it with her. Marie-Thérèse Khair Badawi talks of her clinical practice in a context that "where the unexpected commands"-namely the context of war (Khayr Badawi, 2011). The patient wants to be recognized as prejudiced, and asks me to have compassion for her, to experience human feelings. Time is needed for the work to address this entanglement of the individual and the collective, for the analyst to re-launch Oedipal dynamics and the infantile sexuality (the patient later finds memories of oranges at her grand-mother's, the ice-cream offered by her father in Damascus, stories that her mother used to tell her).

\section{Conclusion}

Listen and welcome stories and words with humanity, so that we can revive the psychic movement that is 
expressed in a common language where the "vous" doesn't exist, making the closeness even closer. My patients (Muslim or Christian, Sunnites or Druze) speak the same language: Arabic. Language carries a libidinal, affective, sensory, gustatory and olfactory charge. The affective, libidinal dimension is very important in this work with refugees. The libidinal resources of the language offer patients, in clinical work, a handling (Winnicott) that is necessary for their psyche. Faced with exile and the pain of loss, language can be a support, a prop, on which to establish a desire for life (Maha tells me: "the only thing I have left is my language") on the condition that this desire exists strongly in the other, here, the analyst.

\section{References}

Abdelouahed, H. (2015). Femmes en temps de guerre. Pétrifications et réserves figuratives de l'hystérie (Women in wartime. Freezing and figurative reserves of hysteria). In Cliniques méditerranéennes, 92, 85-96.

Altounian, J. (1997). Sur l'hébergement psychique. Écrire la rupture réinstaure l'héritage (About psychic lodging. Writing the break institutes the inheritance). L'inactuel, 7, 59-75.

Altounian, J. (2000). La survivance (The survival). Dunod.

Altounian, J. (2011). L'intraduisible (The untranslatable). Dunod.

Fédida, P. (1992). Crise et contre-tranfert (Crisis and counter-transference). PUF.

Fédida, P. (2007). Humain, déshumain (Human, dehumanized). PUF, Petite Bibliothèque de Psychanalyse.

Freud, S. (1984). Considérations actuelles sur la guerre et sur la mort (Thoughts for the times on Wr and death). Essais de psychanalyse (Psychoanalysis essays), Payot, (Petite bibliothèque), 9-40.

Freud, S.(1940). Pulsions et destins des pulsions (Instincts and their vicissitudes). In Métapsychologie (Metapsychology), Gallimard, 11-44.

Freud, S. (1985a). L'inquiétante étrangeté (the Uncanny). In L'inquiétante étrangeté et autres essais (The uncanny and other essaies). Gallimard, col. Folio, 211-263.

Freud, S. (1985b). La négation (The negation). In Résulats, idées, problèmes (Results, ideas, problems), II, PUF, 135-139.

Freud, S. (1985c). Pourquoi la guerre (Why war)? In Résultas, idées, problèmes (Results, ideas, problems), II, PUF, 203-215.

Geffroy, Y. (2015). Images de l'identité: pièges de l'autochtonie (Images of identity: Trops of autochthony). In Les infortunes de l'identité culturelle (The misfortunes of cultural identity), Publications de l'Université internationale de Rabat, 137-150.

Green, A. (1988). Pourquoi le mal (Why evil)? Nouvelle Revue de Psychanalyse (The new psychoanalysis review), 38, $239-261$.

Janin, C. (1996). Figures et destins du traumatisme (Figures and destinies of trauma). PUF.

Khair Badawi, M. T. (2011). Être, penser, créer: quand la guerre attaque le cadre et que le transfert contre-attaque (Being, thinking, creating: When the war attacks the sitting). In Revue Française de Psychanalyse (French psychoanalysis review), 1035-1043.

Mijolla Mellor, S. (2011). de, La mort donnée (The given death). PUF, col. Quadrige. 